\title{
Recent Developments in the Thought of Quentin Skinner and the Ambitions of Contextualism
}

\section{Robert Lamb ${ }^{1}$}

\section{Introduction}

There have been few more influential figures in the Anglophone study of political thought in recent years than Quentin Skinner. Among the many features that characterised his energetic initial writings — in the late 1960s and early 1970s — was his comfort in writing both as a historian of philosophy and as a philosopher of history. As well as offering path-breaking interpretations of the intellectual context of seventeenth century writers like Hobbes, Skinner also offered a distinct, often controversial, methodological programme rooted in claims about the nature of historical understanding. His unique strand of linguistic contextualism—which he suggested was indebted to Collingwood, Wittgenstein and Austin—-has undeniably had a transformative effect on how intellectual historians conceive of their craft. In the early 1980s, he began to speak in another scholarly voice: that of political theorist, as he engaged in a project of 'excavating' and defending a neo-classical understanding of human liberty, which, he argued, was popular among early-modern republicans but then usurped by a modern liberal alternative. ${ }^{2}$

His excavation of republican liberty—and the fusion of historical enquiry and abstract philosophical analysis it involves - has continued to dominate his recent work

\footnotetext{
${ }^{1}$ Department of Politics, University of Exeter, UK, r.lamb@ex.ac.uk. An earlier version of this paper was presented to the American Philosophical Association (Pacific Division) Conference in Pasadena in March 2008. For comments and criticism I am grateful to the audience there, especially Kinch Hoekstra, and the $J P H$ referees. My understanding (such that it is) of Skinner's position has benefited hugely from conversations with Mark Bevir, Dario Castiglione and Iain Hampsher-Monk, though this should not be taken to imply that they all agree with my reading.

${ }^{2}$ His initial interest in the fate of republican conceptions of liberty stemmed from his work on Machiavelli. For the earliest statement of this thesis, see Skinner 'Machiavelli on the Maintenance of Liberty', Politics 18: 1, 3-15. For the more recent version, see Liberty Before Liberalism (Cambridge, 1998) and several of the essays in Visions of Politics, Volume II: Renaissance Virtues (Cambridge, 2002).
} 
at the expense of any concern with the philosophy of history. His only contribution to philosophical debates about issues in historical understanding has been a collated edition of his earlier articles in revised form, entitled Regarding Method. In this article, I suggest that this book is more important than it might otherwise appear and that this is partly because of the revisions that Skinner makes to his original contentions. Rather than focus mainly on the philosophical problems with the revised version of his contextualism ${ }^{3}$, the three main themes I explore in this article are: first, the nature of recent developments in his thought; second, what might be termed the theoretical and political ambitions these developments reveal; and third, why these ambitions appear unsustainable. I begin by suggesting that Regarding Method reveals Skinner as the only figure of his generation still determined to justify an exclusively linguistic contextualist method of historical understanding. I then go on to discuss the way in which his methodology is now recast along anti-foundationalist lines and how this plays out in his representation of the historian as 'archaeologist' interested in 'rhetorical redescription'. After this, I move on to assess Skinner's attempt to present contextualism as a distinct critical approach to political philosophy, which I suggest is less than convincing.

\section{Skinner's Contextualism Recapitulated}

Mark Bevir has offered a critical, historicized reading of 'Cambridge School' linguistic contextualism, which stresses the intellectual background that framed its emergence. Herein, he argues that the lack of recent methodological interventions from its best-known proponents is revelatory of its historical specificity and also

\footnotetext{
${ }^{3}$ For my assessment of Skinner's recent work as a systematic philosophy of history, see R. Lamb 'Quentin Skinner's Revised Historical Contextualism: A Critique', History of the Human Sciences (forthcoming).
} 
points to its philosophical weaknesses. ${ }^{4}$ As Bevir correctly observes, the once trenchant methodological defences of contextualism advanced by its two best-known proponents - Skinner and J.G.A. Pocock — have not been readily forthcoming in recent years. ${ }^{5}$ The plausible conclusion he reaches is that this represents a 'retreat from strong methodological claims'. ${ }^{6}$ But arguably there has been no such substantial retreat by the adherents of contextualism. Most of the evidence for such a retreat concerns the silence from the initial advocates of contextualism. It is true that, while there have been a large number of historical studies completed by both Pocock and Skinner in the last twenty years, this period has not seen any systematic defence of their interpretive principles or response to their numerous critics. Nor have the first, second or third generations of contextualist scholars really taken up the cudgels on their behalf. In the case of Pocock the silence is probably beyond any dispute: he notes in the recent reissue of The Machiavellian Moment that he has not made any statements on method for over twenty years. ${ }^{7}$ His silence is perhaps not so surprising, since his methodological writing has seemed to be comprised of evolving reflections on his historical practice. This accounts both for its piecemeal presentation and its sudden, unexplained shifts in loyalty towards concepts, something exemplified by his

\footnotetext{
${ }^{4}$ The narrative Bevir constructs is one that views the leading figures of the Cambridge School as having grasped at various theoretical currents and vocabularies to justify their historical endeavours, with the result being ultimately incoherent methodological claims cobbled together from disparate philosophical sources. See M. Bevir, 'The Contextual Approach' in G. Klosko (ed.), The Oxford Handbook of the History of Political Philosophy (Oxford, forthcoming).

${ }^{5}$ As other commentators have noted, Skinner and Pocock defend quite distinct and not necessarily compatible methodological approaches, with the former focusing on particularistic 'speech-acts' and the latter on trans-historical 'languages'. See Pocock Virtue, Commerce, and History: Essays on Political Thought and History, Chiefly in the Eighteenth Century, (Cambridge 1985), 1-34 for his take on the difference. For further discussion of the similarities and differences between their two approaches, see Bevir 'The Errors of Linguistic Contextualism', History and Theory 31 (1992), 276-98 where the difference is expressed as one of 'soft' (Skinner) and 'hard' (Pocock) linguistic contextualists; and also I. Hampsher-Monk ‘Speech Acts, Languages or Conceptual History?’ in Hampsher-Monk, K. Tilmans and F. Van Vree (eds.) History of Concepts: Comparative Perspectives (Amsterdam, 1998).

${ }^{6}$ M. Bevir, 'The Contextual Approach'.

${ }^{7}$ J.G.A. Pocock, The Machiavellian Moment: Florentine Political Thought and the Atlantic Republican Tradition (Princeton, 2003), 553.
} 
short-lived commitment to the Kuhnian 'paradigm'. ${ }^{8}$ Moreover, Pocock often tends towards an account of the emergence of contextualism that stresses its historical specificity as a movement rather than any philosophical unity it might be thought to possess. ${ }^{9}$ When viewed now, his work fits well into Bevir's historicized account of contextualism that views it not as an attempt to build a coherent programme, but rather as something philosophically fragmented.

However, if silence is to be considered evidence of a meaningful recantation of methodological precepts, it cannot be attributed so neatly to Skinner. As noted, it is true that Skinner has not published many completely new writings either on the philosophy of history in general or on narrower methodological issues in the last twenty years. ${ }^{10}$ And it is also true that his historical practice has moved in such a way as to clearly imply some repudiation of his strictest contextualist claims; most obviously in his recent tendency to utilise past political thought in contemporary philosophical debates, something that flies in the face of his earliest methodological arguments. ${ }^{11}$ Nevertheless, Skinner has actually been quite defiant in the representation of his methodological work; and part of this defiance amounts to a

\footnotetext{
${ }^{8}$ See especially Pocock, Politics, Language and Time: Essays on Political Thought and History (London, 1972), 3-41.

${ }^{9}$ See, to an extent, Pocock's Introduction to Virtue, Commerce, and History but especially his 'Quentin Skinner: The History of Politics and the Politics of History', Common Knowledge 10 (2004), 532-550.

${ }^{10}$ The lengthy 'Reply to my Critics' included in James Tully's Meaning and Context: Quentin Skinner and his critics (Cambridge, 1988), 233-288 had been his last intervention in debates in the philosophy of history.

${ }^{11}$ Skinner's early methodological writing flatly denied that past thought could be used in this way because of the non-existence of 'perennial problems' in philosophy (see Skinner, 'Meaning and Understanding in the History of Ideas' in Tully (ed.) Meaning and Context). Much of his (especially recent) historical writing, most notably that on the republican idea of liberty, obviously presupposes that there can be perennial problems, in this case the problem of how best to understand the concept of human freedom. Interestingly, although he later conceded - in his 1988 'reply to critics' - that some of his statements on perennial problems 'went too far' (Meaning and Context, 283), this concession is actually omitted from the revised version of the 'reply' contained in Regarding Method while the original denial from 'Meaning and Understanding' remains (88), implying a strengthening rather than weakening of his methodological claims on this issue. For attempts to rehabilitate the case for the existence of the perennial in philosophy, see M. Bevir 'Are There Perennial Problems in Political Theory?', Political Studies 42 (1994), 662-75 and R. Lamb 'Quentin Skinner's Revised Historical Contextualism'.
} 
resistance to any historicized account of its importance. Indeed, his most recent foray into methodological debates shows his committed rejection of any reading of his project as historically limited. Regarding Method is comprised of revised versions of previously published essays, some of them dating back as far as the 1960s. But their republication is clearly not intended to function as some sort of historical document, something suggested by the fact that they have been revised at all. Skinner justifies their publication on the grounds that 'they continue to be discussed in the scholarly literature' and remain of philosophical relevance. ${ }^{12}$ His stated aim is to offer an 'articulation and defence' of his methodological programme, a programme that he summarises with the following contention: 'if we are to write the history of ideas in a properly historical style, we need to situate the texts we study within such intellectual contexts and frameworks of discourse as enable us to recognise what their authors were doing in writing them'. ${ }^{13}$

The nature of Regarding Method thus strongly suggests that Skinner has not dropped the strong methodological claims that characterised his early work. This, taken together with the silence of others, means that insofar as contextualism has a present existence, this is it. But it is arguably not only contextualism's present but also its future. It seems likely that emerging scholars working on contextualist intellectual histories will forego a trawl through various journals and edited collections to find Skinner's articles from the 1960s and 70s, when looking for a methodological justification for their favoured interpretive approach, simply because Regarding Method provides the most useful digest of his thought. It is his particular methodological defence of contextualism that is likely to be what aspiring contextualist intellectual historians regard as the single philosophical justification for

\footnotetext{
${ }^{12}$ Skinner, Regarding Method, vi.

${ }^{13}$ Ibid, vi-vii, emphases added.
} 
and explanation of their craft and therefore might actually be Skinner's legacy in the philosophy of history.

\section{From Detective to Archaeologist: Skinner's Anti-Foundationalist Turn}

The most striking recent development in Skinner's methodological writing has been the ostensibly anti-foundationalist turn it has taken. Though many of the details of the method he defends remain the same, the way in which it is presented and justified has actually shifted quite dramatically. Its presentation has moved from an interest in speech-act theory seemingly reliant on traditional objectivist assumptions about the nature of an interpretive method, to an explicitly anti-foundationalist concern with 'rhetorical redescription' and the social utility of the historical studies such a concern enables. This is evident from his vision of the historian as 'archaeologist' committed not to the discovery of historical facts but rather to the 'excavation' of alien concepts justified with reference to the political use of such an excavation.

The classic expression of the deductive method employed by Sherlock Holmes is his oft-quoted declaration that "when you have eliminated the impossible, whatever remains, however improbable, must be the truth' ${ }^{14}$ Holmes' dictum can be plausibly understood in two different ways. On the one hand, it can be understood as something akin to 'Ockham's Razor', a mere motto, one that advises people to keep to the most basic evidential elements when constructing a hypothesis and avoid constructing elaborate theories when they are not required. But on the other, the dictum can be interpreted as something approaching an exclusivist methodological claim. It seems that in his early work Skinner conceives of the role of the historian as something akin

\footnotetext{
${ }^{14}$ Despite this declaration (in The Sign of Four) Holmes' deductive and inductive techniques evinced over the course of his cases are actually more various and more complex than this dictum suggests.
} 
to a detective bound by the latter understanding of Holmes's dictum and thus offers a particular method capable of revealing historical facts.

This is because Skinner claims that adequate historical understanding depends on the use of speech act theory: the insight that individual locutions are necessarily performative utterances; when individuals say things, they do things in the process, like warning, declaring, promising and so on. ${ }^{15}$ His claim is that grasping the meaning of an utterance requires a grasp of its illocutionary force: it is necessary to understand not just what the individuals words themselves mean (in a semantic sense) but instead what an actor was doing in saying such words to a particular person on a particular occasion. So, in one of his most favoured examples, Skinner refers to Machiavelli's statement that 'mercenary armies always undermine liberty'. ${ }^{16}$ As Skinner notes, whilst 'there is little difficulty about understanding the meaning of the utterance itself', this tells us nothing about what Machiavelli was doing in uttering it, which he claims requires focus on the linguistic context that framed its composition. ${ }^{17}$

In his well-known essay 'Meaning and Understanding in the History of Ideas', first published in 1969, Skinner's view is that the key to uncovering historical meaning lies in determining the conditions of possibility for an individual action to have taken place and that these conditions of possibility can be determined through the application of a particularistic form of speech-act theory. The claim is that if historical texts are properly appreciated as localised speech-acts, the historian can reveal the available linguistic conventions to determine the individual's intention in making the utterance. This involves a process of elimination whereby historical knowledge of existing conventions excludes certain types of action on the basis that

\footnotetext{
${ }^{15}$ Skinner, 'Conventions and the understanding of speech-acts, Philosophical Quarterly 20 (1970), 118-38 and Skinner, 'Reply to my critics' in Tully (ed.), Meaning and Context: Quentin Skinner and his critics (Cambridge, 1988), especially 259-85.

${ }^{16}$ Skinner, 'Reply to my critics', 275.

${ }^{17}$ Ibid.
} 
engagement in them is definitively impossible. So, the 'appropriate method' for historical understanding is one where historians

'delineate the whole range of communications which could have been conventionally performed on the given occasion by the utterance of the given utterance and, next, to trace the relations between the given utterance and [the] wider linguistic context as a means of decoding the actual intention of the given writer'. ${ }^{18}$

According to Skinner, this process comprises the "necessary conditions for the understanding of utterances'. ${ }^{19}$

On this basis, the historian can approach the writings of historical thinkers and exclude certain interpretations of them as definitively anachronistic. Anachronisms are here understood as a category of erroneous interpretation that arises whenever historians ascribe to individuals intentions that they were incapable of holding. One example that Skinner uses to illustrate this concerns the political thought of John Locke, which he argues cannot be correctly interpreted or described it as 'liberal'. 20 Crucially, the basis he provides for regarding this interpretation or description as incorrect does not have anything to do with evidence about Locke's political thought itself. It has nothing to do with any particular feature of Locke's writings, nothing to do with whether aspects of his thought are not plausibly describable as liberal—for example, his belief that no political society should extend toleration to atheists. Skinner's charge of anachronism is not based on any substantive analysis of Locke's ideas but rather the historical conditions of possibility necessary for the interpretive claim to be considerable in the first place. The reason that Locke's writings are illegitimately describable as 'liberal' is, for Skinner, that it is impossible to identify the conventional intention of wishing to advance a liberal political theory, because

\footnotetext{
${ }^{18}$ Skinner, 'Meaning and Understanding in the History of Ideas' in Tully (ed.), Meaning and Context, 63-64.

${ }^{19}$ Ibid.

${ }^{20} \mathrm{Ibid}, 45$.
} 
such a convention was not yet in linguistic existence. As with the strong reading of Holmes's dictum, the conventionalist method defended in Skinner's early writing is committed to a vision of understanding history that depended on eliminating the impossible to reveal the facts of the matter at hand.

His conventionalist approach that involves 'decoding' an individual's utterance seems more than just an interpretive technique that any historian can legitimately opt to discard and still reach valid interpretive conclusions. Rather Skinner gestures towards presenting his method as one capable of establishing an objectively true interpretation of a text. This is because, as he puts it, understanding and identifying the linguistic conventions available to an author is a 'necessary condition' for comprehending her utterance. Skinner certainly does not describe it as a sufficient condition: he does not say that identifying all the linguistic conventions available to an author provides a guaranteed route to correct interpretation. But, nevertheless, in labelling the knowledge of linguistic conventions a necessary condition of understanding, he does maintain that any successful route-regardless of the particular method used therein-will definitely require a conventionalist analysis. Without knowledge of all of the range of conventional communications that Locke could have engaged in, sound interpretation is impossible, even if such knowledge does not absolutely guarantee successful interpretation. ${ }^{21}$

\footnotetext{
${ }^{21}$ Because of this, I think that Mark Bevir is right to read Skinner as committed to something resembling a 'logic of discovery' for the historical understanding. See Bevir, The Logic of the History of Ideas (Cambridge, 1999), 80-98. This interpretation is not universally accepted however and some commentators still insist that Skinner's writings on method are really best read as advice on interpretive techniques. So, for example, this alternative reading does not say that Skinner actually denies the existence of perennial problems in philosophy, but rather says something like 'the historian should not assume that there are perennial problems as doing so can lead to mistaken interpretive claims'. I think the alternative, heuristic reading of Skinner's project, though potentially legitimate, faces two issues: first, it sits ill with Skinner's more intemperate criticisms of other approaches, such as those that approach texts as containing universalistic, abstract propositions; and, second, that Skinner's importance as a philosopher depends on him being the proponent of the stronger reading of his project — put bluntly, why would philosophers be interested in his writing in the first place if his claim
} 
Skinner's claims about the nature of correct interpretation remain largely unchanged in the revised versions of his various essays. ${ }^{22}$ Yet Regarding Method reveals a rejection of the foundations that would seem necessary to underpin this approach to historical understanding. In one of the newer essays in the volume, Skinner rejects the master/apprentice model of historical training outlined by Geoffrey Elton, especially its assumption that 'the proper task of the historian is simply to uncover the facts about the past and recount them as objectively as possible'. ${ }^{23}$ Skinner's critique of Elton involves two key claims: (1) a rejection of his commitment to objectivity in historical enquiry and (2) a rejection of his view of why historical enquiry might be thought an important activity. The first claim, which concerns Elton's alleged subscription to 'the cult of the fact' that reveals Skinner's newfound adherence to anti-foundationalism. ${ }^{24}$ According to Skinner 'scarcely anyone nowadays believes in the possibility of building up structures of factual knowledge on foundations purporting to be wholly independent of our judgements' and because of this the objectivist approach associated with Elton is 'untenable'. ${ }^{25}$ This rejection of foundationalism indicates a shift in Skinner's because some commitment to objectivity seems implicit in his account of a method that stipulates the necessary conditions for historical understanding. Any claim about the necessary conditions of understanding grounds objective knowledge in ways that is difficult to square with any denial of the existence of facts in the way Skinner seems determined to in offering what he describes as a 'post-empiricist critique'. ${ }^{26}$

that 'we should study the linguistic context' has the same status as the claim that 'we should read the book with the lights on'?

${ }^{22}$ See Skinner, Regarding Method, 73-74, 86-87.

${ }^{23}$ Ibid, 9.

${ }^{24}$ Ibid, 8.

${ }^{25}$ Ibid, 1.

${ }^{26}$ Ibid, 1. In an interview Skinner has claimed that he has 'always been an anti-foundationalist', something that he traces in part to his time at Princeton and encounters with Richard Rorty and Clifford Geertz. See Petri Koikkalainen and Sami Syrjämäki, 'On Encountering the Past - Interview with 
The second claim about the social value of the historian - though no doubt rather uninteresting as a statement in the philosophy of history-actually connects to a quite important further development in his thought. For Skinner, Elton provides an impoverished account of the nature of history as an area of academic enquiry because it stresses the necessity of scholarly technique over broader social purposes. Unlike Elton, for whom the purpose of historical studies can be reduced to features intrinsic to the practice - like 'the intellectual training' it provides — for Skinner its purpose is to make 'a contribution to the understanding of our present social world' and, correspondingly, to check any tendency to 'fall under the spell of our own intellectual heritage' ${ }^{27}$ For Skinner, the study of history 'can help to liberate us from the grip of any one hegemonal account of those values and how they should be interpreted and understood'. 28 'History', he suggests, has 'the power to transform us, to help us think more effectively about our society and its possible need for reform and reformation'. ${ }^{29}$

This stress on the social value of historical enquiry might be thought neither remarkable in itself nor a particularly dramatic development in Skinner's thought. It could perhaps be read just as a fairly innocuous dig at Elton's conservative suspicion of all theoretical reflection and a response to the charge of antiquarianism that Skinner's own contextualism has occasionally faced. ${ }^{30}$ But when considered alongside the first claim — that Elton's approach reveals a naïve belief in objective knowledge and an adherence to the 'cult of the fact' - it becomes more significant. As Skinner

\footnotetext{
Quentin Skinner', Finnish Yearbook of Political Thought 6 (2002), 32-63. Nevertheless, I cannot see how any commitment to anti-foundationalism (understood as a rejection of the thesis that our knowledge can have securely objective foundations in observation or reason) can be squared with a theory of historical understanding that regards the use of some methods as a necessary route to objective understanding, which automatically rules other methodological approaches out. Antifoundationalism would surely rob Skinner of the ability to privilege one approach over another.

${ }^{27}$ Ibid, 21, 6.

${ }^{28}$ Ibid, 6.

${ }^{29}$ Ibid, 26.

${ }^{30} \mathrm{See}$, in particular, Charles D. Tarlton, 'Historicity, Meaning and Revisionism in the Study of Political Thought', History and Theory 12 (1972), 307-28.
} 
notes, his proposed rejection of traditional empiricism facilitates a particular vision of the historian: that of an 'archaeologist' whose objective is to excavate ideas from the past, 'bringing buried intellectual treasure back to the surface', the 'alien character' of which can expose us to different ways of thinking. ${ }^{31}$

In his recent book, Liberty Before Liberalism, Skinner suggests that his vision of the historian as archaeologist is an allusion to the work of Michel Foucault, a figure that is absent from his early work but now looms large as an intellectual influence. Although James Tully has often written of parallels in the work of Skinner and Foucault, there actually appears to have been little in common between the two. ${ }^{32}$ What most obviously differentiates them is that the former has always appeared to privilege the author as a locus of analysis whereas the latter often appears to reduce authorial voice to constitutive discursive practices or regimes. ${ }^{33}$ Nevertheless, in his recent work Skinner has embraced this alleged theoretical link. Linked to this embrace of Foucault is an embrace of Nietzsche, another thinker absent from Skinner's earlier work but now invoked as an important influence on his thought. ${ }^{34}$

The Nietzschean/Foucauldian influence appears most substantively in Skinner's account of the 'ideological' underpinnings of moral and political argument. He claims that past political texts should be regarded as having been composed by 'innovating ideologists' ${ }^{35}$ These 'innovating ideologists' are individuals who attempt to rhetorically manipulate key terms through 'sleights of hand' in order to serve specific political strategies in the awareness that 'it is in large part by the rhetorical manipulation of these terms that any society succeeds in establishing, upholding,

\footnotetext{
${ }^{31}$ Skinner, Liberty Before Liberalism, 112; Regarding Method, 126.

${ }^{32}$ See J. Tully, 'The pen is a mighty sword' in Tully (ed.) Meaning and Context.

${ }^{33}$ See, most obviously, M. Foucault, 'What is an author?', Language, Counter-Memory and Practice. This difference is acknowledged but not resolved by Skinner (Regarding Method, 118-19).

${ }^{34}$ Skinner, Regarding Method, 176-77.

${ }^{35}$ Ibid, 148.
} 
questioning or altering its moral identity, ${ }^{36}$ It is in outlining this account of the 'innovating ideologist' — who seeks to rhetorically manipulate key moral terms for strategic political ends - that Skinner declares his 'allegiance to one particular tradition of twentieth-century social thought', one that 'may perhaps be said to stem from Nietzsche'. ${ }^{37}$

One of the effects of this turn towards Nietzsche and away from a seemingly foundationalist commitment to historical facts retrievable through a conventionalist method has been a corresponding reconfiguration of his use of speech-act theory, which has been refashioned to prioritise a concern with 'rhetorical redescription', the process through which innovating ideologists act to change the meanings of important political terms for their own ends. Skinner notes how words that once held negative connotations like 'ambition' or 'patriot' have been rendered either neutral or positive designations thanks to individual manipulation. ${ }^{38}$ This phenomenon is exemplified, he suggests, by Nietzsche's analysis of the triumph of Christian slave morality in The Genealogy of Morals. ${ }^{39} \mathrm{He}$ further insists that such redescriptions suggest a more general philosophical point, arguing — again seemingly along generalised Nietzschean lines - that the purpose of moral and political argument can be reduced to an individual's strategic objectives in making it. This does not appear to be the weaker claim that individuals will, on occasions, behave in such a strategic manner, but rather the stronger claim that they will always do so: for Skinner, the use of evaluative political terms 'will always reflect a wish to impose a particular moral vision on the workings of the social world' ${ }^{40}$ The methodological upshot of this is that a previously broad theoretical concern with illocutionary force and what an individual might have

\footnotetext{
${ }^{36}$ Ibid, 182; 149.

${ }^{37}$ Ibid, 176.

${ }^{38}$ Ibid, 152, 168.

${ }^{39}$ Ibid, 185.

${ }^{40}$ Ibid, p. 182.
} 
been doing in uttering (like declaring, promising etc) has been replaced with a much narrower interest in the purely ideological use of speech and the way evaluative language can be used to legitimate the activities of individuals and groups.

\section{Conceptual History and Critique: Contextualism as Political Theory}

Regardless of whether these recent developments in Skinner's thought — the explicit anti-foundationalist rejection of objectivity, the stress on the social value of historical enquiry and the interest in narrow strategic rhetoric rather than a wide repertoire of speech-acts—can be comfortably reconciled with his earlier arguments, they have allowed him to present his contextualism as something more than just an argument about the nature of history. These developments seem in fact to be part of an attempt to represent contextualism as something beyond a philosophy of history. This can be shown through an examination of how contextualism has been conceived (by Skinner and some of his followers) as a distinct, critical approach to political philosophy.

Despite the indefatigable campaign by historian Melvin Richter to bring it to the fore, the methodological impact of the German conceptual history (Begriffsgeschichte) project — associated with Reinhart Koselleck-on Anglophone scholarship has been negligible, especially in comparison to Cambridge school contextualism. ${ }^{41}$ On the few occasions when it has been taken seriously as involving substantive methodological claims, they are usually thought problematic. This is largely because philosophers have regarded 'concepts' as at best inadequate and at worst implausible units for historical analysis, especially compared with alternatives such as languages, ideas, practices and traditions. But apart from any theoretical

\footnotetext{
${ }^{41}$ Richter's various essays on the subject culminated in his book The History of Political and Social Concepts: A Critical Introduction (Oxford, 1995). His 'call for a history of political and social concepts in English' (143-160) seems as yet unheeded. Conceptual history groups do, however, flourish in various European countries, including Finland, France and Portugal.
} 
problems this approach, commentators have noted the logical incompatibility between the conceptual history project conceived by Koselleck and his followers and the linguistic contextualism defended by Skinner. ${ }^{42}$

Part of this incompatibility relates to the fact that the Begriffsgeschichte project is really a form of social history, whereas the contextualism of the Cambridge School has insisted on bracketing off all analysis of the social in favour of the linguistic. But more seriously, if, as Skinner argues, there can be no 'perennial problems' in the history of ideas and if understanding the meaning of an utterance requires treating it as a particularistic speech-act incapable of abstraction from its locality, then the history of concepts cannot be studied at all. Concepts cannot, on such a particularistic understanding, actually have histories because they will always be reducible to their very discrete deployment. Thus, Skinner declared in his early writing that any attempts at 'tracing the morphology of a given concept over time' are 'necessarily misconceived'. ${ }^{43}$ This is a position that is reiterated, albeit more softly, in Regarding Method: even with the move away towards rhetorical description, he insists that he 'remain[s] sceptical about the value of writing histories of concepts' ${ }^{44}$

Yet in a surprising development in the final chapter entitled 'Retrospect: Studying rhetoric and conceptual change', Skinner attempts a rapprochement with conceptual history and suggests that it and his own contextualism are not only logically compatible but are in fact complementary projects. He suggests the only difference between the two lies in terms of emphasis: that Koselleck and his followers focus on 'the entire process of conceptual change' whilst his own is 'one of the

\footnotetext{
${ }^{42}$ See Hampsher-Monk, 'Speech-Acts, Languages or Conceptual History?' and, more hesitantly, Martin van Gelderen 'Between Cambridge and Heidelberg. Concepts, Languages and Images in Intellectual History' in Hampsher-Monk et al (eds.) History of Concepts, 227-38. Richter has always maintained that the differences do not reveal a substantial incompatibility. See The History of Political and Social Concepts, 124-42.

${ }^{43}$ Skinner, 'Meaning and Understanding', 63.

${ }^{44}$ Skinner, Regarding Method, 86
} 
techniques by which it takes place'. ${ }^{45}$ He makes a point of noting that Koselleck's own work had not been an intended target of his early methodological essays; he suggests that it could not have been, as he had not actually encountered it. ${ }^{46}$ Nevertheless, he does not actually explain at all how contextualism and conceptual history can be thought compatible at the methodological level. The fact that Koselleck was not a target of Skinner's early critical essays does not explain how an insistence on the particularistic understanding of meaning through individual speech-acts could ever cohere with an insistence on the tracing of the histories of individual concepts. Skinner argues that the two approaches share a certain understanding of the social world, specifically how it can be transformed through the contestation of evaluative concepts. His contention is that both contextualism and conceptual history 'assume that we need to treat our normative concepts less as statements about the world than as tools and weapons of ideological debate'. ${ }^{47}$ But this in itself is not enough to sustain any suggestion of compatibility. The issue of incompatibility does not concern how we treat our normative concepts but rather whether we regard concepts as the kind of autonomous entities that can be traced over time and how that claim (if accepted) could ever cohere with Skinner's speech-act theory.

Though Skinner does not demonstrate the compatibility of his contextualism with Koselleck's conceptual history, this task has been attempted by Kari Palonen. Palonen describes the two approaches as 'styles' of political theorizing that each embodies a 'critique of the unhistorical and depoliticising use of concepts'. ${ }^{48}$ And Skinner has come to endorse this view: this is because, for him, the contextualist

\footnotetext{
${ }^{45}$ Ibid, 187.

${ }^{46}$ Ibid, 177

${ }^{47}$ Ibid.

${ }^{48}$ Palonen, 'The History of Concepts as a Style of Political Theorizing: Quentin Skinner's and Reinhart Koselleck's Subversion of Normative Political Theory', European Journal of Political Theory 1 (2002), 91-106 at 102, 91.
} 
approach to understanding political concepts 'offers us an additional means of reflecting on what we believe, and thus of strengthening our present beliefs by way of testing them against alternative possibilities'. ${ }^{49}$ This belief — that a contextualist methodology comprises a 'critical' theory—has also been advanced by James Tully, who suggests it is actually a distinct approach to political philosophy, one that enables 'a kind of permanent critique of the relations of meaning, power, and subjectivity in which we can think and act politically'. ${ }^{50}$ Thus understood by Skinner, Palonen and Tully, contextualism becomes not only a philosophy of history but also a political philosophy and one that not only provides the resources for but also actually embodies critique.

Both Palonen and Skinner claim that contextualism represents a specific critique of the tradition of normative political theory. In fact Skinner asserts that an endorsement of his contextualist 'vision of politics' entails that

'we place a question-mark against all those neo-Kantian projects of our time in which we encounter an aspiration to halt the flux of politics by trying definitively to fix the analysis of key moral terms. I continue to harbour a special prejudice against those who, in adopting this approach, imagine an ideal speech situation in which everyone (everyone?) would make the same moral and cognitive judgements'.

This criticism is clearly aimed at the normative concerns at the heart of the work of figures like John Rawls, Jürgen Habermas and their followers. The argument seems to be that a contextualist understanding of or approach to history facilitates a certain understanding of politics, which acts to undermine normative political theory as a project. Normative theory is rendered problematic by its apparent failure to take seriously the process of conceptual change. In engaging in abstract debates about the nature and demands of key political concepts such as justice or equality, normative

\footnotetext{
${ }^{49}$ Skinner, Regarding Method, 126-127.

${ }^{50}$ Tully, 'Political Philosophy as Critical Activity', Political Theory 30 (2002), 533-555, at 535.

${ }^{51}$ Skinner, Regarding Method, 177.
} 
political theorists illegitimately try to 'fix' the meaning of moral terms, thus ignoring the 'radical contingency' of our values and the necessarily ideological nature of our arguments. $^{52}$

There are, however, several problems with this position, problems that undermine the ambitions that these scholars have for contextualism as a critical theory of politics that challenges other approaches, particularly that of the normative tradition. The first is that the criticism of the normative enterprise offered by these figures depends on a particular understanding of that enterprise and this understanding seems dubious. The contextualist criticism of normative political theory concerns two related issues: (1) the supposed failure to take seriously the 'radical contingency' of the evaluative concepts existing in any society and (2) the attempt to attain some kind of Archimedean point of universality and corresponding failure to realise that "no one is above the battle, because the battle is all there is'. ${ }^{53}$ Both these charges seem to rely on mischaracterisations of the nature of normative theory; both how it is practiced and how it can be practiced.

The first charge seems mistaken since it is the fact that our values are radically contingent and particular that creates the problem of political conflict that animates much normative theory in the first place. Theories of politics such as those offered by Rawls, Habermas and their followers generally take the existence of deep conflict about moral and political principles as a given. ${ }^{54}$ It is the case that these normative political theorists typically deny any thesis of radical incommensurability of moral values, but this is not the same thing at all. The incommensurability of moral values might pose a threat to the normative project in a way that the mere contingency of these values does not. The fact that moral values are subject to spatial and temporal

\footnotetext{
${ }^{52}$ Ibid, 176.

${ }^{53}$ Ibid, 7.

${ }^{54}$ See, for example, Rawls, Political Liberalism (New York, 1993), 36-37.
} 
shifts poses no necessary threat to the project of trying to unpack or systematise norms to assess the conduct of individuals or governments. The second point also relies on a seemingly inaccurate representation of the normative project, since it need not involve any appeal to objective universality, but rather to particular political communities in which there is scope for agreement on moral principles. The depiction of Neo-Kantian normative theorists as 'dispassionate analysts standing above the battle' thus seems inaccurate. ${ }^{55}$ Rawls, even in his early writing, was explicit that his aim in deploying abstract devices such as his 'original position' was to 'make vivid' the intuitions held about moral concepts by individuals within particular societies and then to systematise them into meaningful principles rather than to deduce them from some realm of total abstraction. ${ }^{56}$ But even if Rawls and his followers are understood thus, it does not follow that all normative theorizing need be practiced so. Normative theorizing can be understood simply as the unpacking and systematization of deeply held intuitions about morality.

Another problem with the critical ambitions of the advocates of contextualism goes beyond (and is much more important than) the dubiety of their critique of normative theory. The second problem is that even if the normative project could be so characterised — as the misguided attempt at generating moral principles from pure abstraction without considering the possibility that our evaluative concepts are radically contingent - it remains the case that there is nothing in the theoretical arsenal of contextualism that would pose any real threat to it. This is because there is nothing inherently critical about contextualism as a philosophy of history in the first place. Skinner's main interpretive claim is that in order to be understood, the meaning of an utterance needs to be located within its particular linguistic context and that the

\footnotetext{
${ }^{55}$ Skinner, Regarding Method, 7.

${ }^{56}$ Rawls, A Theory of Justice (Oxford, 1999), 16.
} 
particularity of an utterance is related to the radical contingency of evaluative concepts. But even if this claim were thought sustainable, it does not necessarily provide any resources for, let alone entail, any kind of critical attitude to politics. There is no necessary connection between thinking about history or politics contextually on the one hand and thinking critically in the way Skinner, Palonen and Tully would like us to. Contextualist theorists of history need not be committed to any theory of politics in the same way as theorists of politics (contractarian, critical or otherwise) need not invoke any theory of history. ${ }^{57}$ Critical theorists are likely to bemoan the failure of normative theories to fully account for issues of micropower within any society and lament any belief that conceptual analysis of justice or rights provides a sufficient account of politics. At the same time, normative theorists are likely to bemoan the limitations of critical theories of politics, in particular their failure to acknowledge that ideas of justice and rights can only be dispensed with at the expense of rendering any critique hopelessly question-begging at the level of justification. Both sets of theorists might have a point, but it is hard to see how historical contextualism lends support, or has anything to say, to either.

Not only does contextualism not necessarily lead us to critique, it may actually yield quite different, conservative political conclusions. Skinner assumes that contextualism, because it involves an encounter with beliefs that will necessarily be alien to us, will facilitate a 'greater degree of understanding, and thereby a larger tolerance, for elements of cultural diversity' and a more 'self-critical' attitude. ${ }^{58}$ But this requires something of a leap of faith. Why should we assume that intellectual encounters with alien belief systems from the past encourage people to be more tolerant rather than further entrench whatever prejudices they hold? The relationship

\footnotetext{
${ }^{57}$ I see no grounds for Palonen's assertion that Rawls is 'committed to a philosophy of history'. Palonen, 'The History of Concepts as a Style of Political Theorizing', 96.

${ }^{58}$ Skinner, Regarding Method, 125-26.
} 
between contextualism and the sorts of political claims Skinner wishes to make is at best a contingent one. To say that contextualism gives us the opportunity to avoid being 'bewitched' by the supposedly hegemonic values of a particular society and to recognise their contingency can be seriously considerable only as an empirical claim. Any number of activities can enable us to recognise the contingency of our concepts and there seems no reason to privilege contextualist intellectual history in this regard over reading A Theory of Justice or hiking in the Canadian Rockies.

\section{Conclusion}

It seems almost certain that those familiar with the early methodological essays written by Skinner will have noted several changes in his recent writing. They might perhaps regard these changes as complementary to his recent work as a practising historian of ideas. But it is important to underscore that these are not merely changes in emphasis, style or presentation and not just a change in his interlocutors. Furthermore, they are not any clear repudiation of the claims for which his contextualism became best known and not any concession to his many critics. Rather, his recent writing demonstrates substantial developments in the way in which his contextualism is delineated and justified. In many respects, these developments jar with his previous writing and whether a coherent philosophy of history is retrievable from Regarding Method remains uncertain. What is certain is that Skinner has embraced anti-foundationalism and in doing so has presented his method as less about the treatment as texts as speech-acts and more about strategic rhetorical moves, designed to alter to the social and political world in which an actor exists.

It remains unclear whether and how this anti-foundationalism has encouraged Skinner to follow others and try to recast contextualism as a distinct critical approach 
to political philosophy. But regardless of the link between the two this recasting, as I suggested above, is unconvincing. Even if contextualism could be justified in terms of a method that outlines the necessary conditions of understanding, it cannot be successfully represented along the lines Skinner and others have suggested. Not only is contextualism incapable of being conceived as a fundamentally critical approach to politics, it is difficult to see how any philosophy of history could be understood in this way. Some extra work needs to be done to explain not only how it is possible to derive a critical approach to politics from a particularistic philosophy of history but also how it is possible to derive any theory of politics from philosophical assumptions about the nature of history. Past thinkers — most obviously Hegel and Marx — might have attempted such a derivation quite brazenly, but it is because their theorizing explicitly meshed assumptions about fact and value and did so in such a way that no contemporary philosophers could ever find convincing. 